\title{
The future of Spanish public universities: The challenges of a discourse of excellence
}

\author{
El futuro de la universidad pública española: \\ desafíos ante el discurso de excelencia
}

\author{
Le futur de l'université publique espagnole : \\ défis devant le discours d'excellence
}

\section{Luján Lázaro Herrero}

University of Salamanca, Spain

\begin{abstract}
This study aims to analyze the challenges facing Spanish public universities at a crucial moment for defining their essence. The political, economic, and social circumstances of the current moment oblige us to reflect on the role that universities should play. This reflection will be essential in responding to the ever more exacting demands of market economies, the kinds of societies in which these institutions are immersed. Therefore, this paper tries to analyze the repercussions that global changes in politics and economics are having on public universities in Spain. Once again, we shall discover how globalization processes determine the education planning of a country. On this point, the compass of governance has set the course of the educational institutions for economic efficiency, following a set of market criteria that involve their own funding and results.
\end{abstract}

Key words: higher education, Spanish university, academic excellence, accountability, university reform.

\section{RESUMEN}

El objetivo de este trabajo es analizar los retos a los que se enfrenta la universidad pública española en un momento que se presenta como crucial para la definición de su esencia. Las circunstancias políticas, económicas y sociales que dibujan el panorama actual obligan a reflexionar sobre el papel que debe jugar la universidad hoy en día. Éste va a ser esencial para dar respuestas a las demandas, cada vez más exigentes, de las economías de mercado, sociedades en las que se hallan inmersas. Por ello, este artículo trata de examinar las repercusiones que los cambios políticos y económicos están teniendo en las universidades 
públicas de España. Una vez más, podemos descubrir cómo los procesos de globalización determinan la planificación educativa de un país. En este punto, la brújula de la Gobernanza ha fijado el rumbo de las instituciones educativas hacia la eficiencia económica, siguiendo una serie de criterios de mercado que pasan por su propia financiación y por los resultados de la misma.

Descriptores: educación superior, universidad española, excelencia académica, rendición de cuentas, reforma universitaria.

\section{RESUME}

L'objectif de ce travail es celui d'analyser les défis auxquels l'université publique espagnole s'affronte dans un moment que se présente comme crucial pour la définition de son essence. Les circonstances politiques, économiques et sociales qui dessinent le panorama actuel obligent à réfléchir sur le rôle que l'université doit jouer de nos jours. Ce rôle va être essentiel pour donner des réponses aux demandes, chaque fois plus exigeantes, de part des économies de marché, sociétés dans lesquelles elles y sont immergées. Pour cela, cet article traite d'examiner les répercussions que les changements politiques et économiques ont sur les universités publiques en Espagne. Ainsi, nous découvrirons, encore une fois, comment les processus de globalisation déterminent la planification éducative d'un pays. A ce point, la boussole de la Gouvernance a fixé le cours des institutions éducatives vers l'efficacité économique, en suivant une série de critères de marché que passent par son propre financement ainsi que par ses résultats.

Mots clés: education supérieure, université espagnole, excellence académique, obligation redditionnelle, réforme universitaire.

\section{Introduction}

"Further progress would be in order." This seems to be the catch phrase that the Expert Committee on Reform of the Spanish University System ${ }^{1}$ - appointed by the Minister of Education, Culture and Sport, José Ignacio Wert - espouses to refer to the current university sector. The report "Proposals for the Reform and Improvement of Quality and Efficiency in the Spanish University System" 2 calls for a social debate about the role of higher education institutions, and stresses the need to undertake a series of changes considered essential and indeed unavoidable. These changes would affect all spheres of university life and pursue the goals of academic excellence and international competitiveness.

In recent years, many studies have addressed the Spanish University System (SUS). The determination to diagnose the situation, both internally and externally, enables us to

\footnotetext{
${ }^{1}$ A committee made up of eight university professors and an economist representing the Banco Santander.

2 This report was delivered to the Minister of Education, Culture and Sports on 12 January 2013. It includes an addendum with considerations of two of the members of the committee.
} 
discover the details, causes, and ills of a model that for some authors "is totally exhausted" (Arenilla, 2012, p. 13). This reformulation of identity arises within a context marked by a world economic crisis, leading to cuts that, in Spain, have materialized to the detriment of public services. The reduction of the public budget is now seriously jeopardizing the Welfare State. In this sense, health, social welfare, and education are all affected by these cuts, and this is especially pressing in the case of universities since - over and above their educational role - they are key players in the generation of knowledge and cultural, social, and economic change (Grau, 2012). Their contribution thus goes far beyond teaching and research. Faced by burgeoning international competition, universities now hold a key position in the social and economic development of countries.

The truth is that education lies at the heart of the growth of a country. Accordingly, universities must be seen as a major factor in the advancement of social prosperity. Bearing in mind the dizzying progress of the knowledge society, it is clear that we need to consider proposals for the future that are able to identify ways towards improvement and development, if we are to build a higher education system that is sturdy and resistant to the gale-force winds buffeting the current situation.

In this regard, in an attempt to make the challenges currently faced by the SUS more explicit, Grau (2012) raises a series of questions that, if answered in the affirmative, might be able to outline the challenges that he feels that the Spanish university sector faces in this first third of the twenty-first century:

- Is it possible to improve the levels of confidence that Spanish society generates in its universities?

- Can the effectiveness and efficiency of universities be improved by reforming the system of governance?

- Can the effectiveness and efficiency of the research system in Spain be improved within a context of budgetary restraint?

- Can we foster the transformation of new knowledge into innovation in products and processes and thereby improve the country's competitiveness in the medium term?

- Does the country have the tools to make such changes possible? (p. 4)

Every new debate about university reform seems to take us back to square one, as if we were playing a game of Snakes and Ladders. For one faction, in an environment that is both powerful and at the same time ultraconservative, it is resistance to change that makes any progress impossible. For the other, the fault lies with the pressure groups that time and again insist on charging the atmosphere with misguided neo-liberal, mercantilist proposals to create a model for universities in which they should operate like companies in the private sector, forfeiting their role as a public service: "For a long time now the university sector has been at the forefront of a process of mercantilism." Authors Besalú, Marqués, and Soler $(2013$, p. 1) and others express themselves in these terms when referring to education as being deemed yet another product to be bought and sold, regulated by the laws of supply and demand, offering more "profitable" courses, and placing emphasis on the economic potential of its "customers." 
It is not uncommon to hear comments to the effect that the Spanish university sector is not so awful, if the precarious circumstances from which it started are taken into account. Similarly, we find testimonies that, even though accepting that change is necessary, are not satisfied with the remedies proposed (Aunión, 2013).

This article analyzes the initiatives being taken by universities under pressure of several demands that, through political measures, urge it towards the achievement of results in terms of academic excellence. To do so, the argument revolves around what some authors, such as Llinás-Audet, Girotto, and Solé (2011), understand to be the most outstanding challenges in which these institutions are immersed: modification of the governance systems, changes in funding habits, and increased internationalization.

\section{A diagnosis of the Spanish university system}

One aspect that illustrates the current scene in higher education in Spain can be found in the number of institutions providing it. It should be noted that in recent years the number of universities has grown, which would not appear to be the most opportune course of action for the current interests of the country.

In the 2013/2014 academic year, the SUS encompassed a total of 82 universities, 80 of which provided teaching (MECD, 2014). The institutions were spread over 236 campuses offering face-to-face teaching and 112 centres for online and special courses. Of the 82 universities, 50 are public and 32 are private. In recent years, the number of private universities has also grown; since 2001, fourteen institutions of this type have appeared, almost one every year.

In Spain, there are 1.75 universities per million inhabitants. If we take into account only the traditional college-age population (between 18 and 24 years of age), the number of universities per million inhabitants is around 24.6. Put another way, in Spain there is a university for every 569,852 inhabitants, and if only the population between 18 and 24 years of age is taken into account, there are 40,584 young people per university. If in the final breakdown we consider only the total university population (undergraduate, graduate, and Master's students), on average there are 19,000 students per university.

Thus, a scene unfolds of 1,030 university campuses (schools and faculties) offering official teaching throughout the whole of Spain. The data reveal a broad geographical distribution of universities, with the larger Autonomous Communities having the highest concentration of institutions: Andalusia (151), Catalonia (150), and Madrid (156). There are 2,998 departments currently on record, including 599 in Madrid, 544 in Andalusia, and 376 in Catalonia. There are 481 Research Institutes, 29 Doctoral Schools (though these institutions are at the development stage, as per Royal Decree 99/2011 of 28 January), and 47 teaching hospitals.

As well as the establishment of new universities and institutes, the catalogue of university courses has also increased, diversifying and tailoring the Spanish academic offer. This is one of the aspects that is currently of most concern for education managers, who see before them the prospect of challenges that must necessarily include the streamlining of universities. Fostering mergers of higher education institutions and reducing the multiplicity and overlapping of courses is one of the key elements when tackling such 
reform. Minister of Education José Ignacio Wert (2012) stated: "The general conclusion is that there are too many universities, or at least there are too many courses." Too little specialization, and shared or repeated courses, often overlapping within limited geographical areas, are the main negative aspects in this context. These weaken the universities themselves, leading to unhealthy financial competition (Expert Committee, 2013).

In the eyes of the Spanish government, it seems that the SUS is very deficient, and this is indeed corroborated by the startling (and lamentable) lack of first-class universities in Spain. Moreover, university education does not enable students to obtain jobs commensurate with their qualifications, which is tantamount to saying that the universities do not prepare them for obtaining a qualified position in the job market.

Nevertheless, this diagnosis of the Spanish university situation is not shared by many in the teaching community. In fact, in a press release of 16 April 2012, the Conferencia de Rectores de Universidades Españolas (Conference of Rectors of Spanish Universities/CRUE) claimed that results in research, teaching, and knowledge transfer are far greater than the public effort expended, as confirmed by many national and international organizations. The CRUE press release characterized Spanish universities in the following ways:

- In teaching, $79 \%$ of students who start courses graduate with a university degree, compared to the OECD average of $70 \%$.

- In research, between 1997 and 2007, Spanish scientific output grew by 80\%, comprising $3.4 \%$ of global scientific output, two thirds of this percentage being carried out in universities. This effort has made Spain the ninth highest contributor to scientific output and the eighth highest in terms of per capita publications.

- In the transfer of knowledge, Spain certainly contributes very little (0.8\%) to global patents. Despite this, the percentage of patents that come from the university sector in Spain is the second highest in the world. (CRUE, 2014)

In summary, the CRUE report aimed to vindicate the role of universities as the drivers of social and economic development. This framed their request for funding in keeping with the country's needs to overcome this period of crisis.

SUS activities are conducted within the framework of the so-called knowledge triangle, made up of education, research, and innovation (see Figure 1). The vigour offered by the SUS in teaching and research should be noted, but it is unfortunately lessened by a lack of adaptation of the educational offerings to the demands of the Spanish economy and an absence of input from investments in research, development, and innovation from outside companies. Pastor and Peraita (2012), in their study of the socio-economic contribution of the SUS, highlight its positive appraisal from different spheres of influence because it has generated a marked expansion and diversification of official university degrees, and universities can be seen as an important and profitable investment by the Spanish government. 
The 2013 Fundación Conocimiento y Desarrollo (Knowledge and Development Foundation/CYD) report highlights a number of trends in the contribution of the universities to Spain's social and economic development. The contribution of universities as trainers of human capital, the importance for universities of their relationships with companies, and the nurturing of an entrepreneurial culture within them are the three fields that have improved the most. By contrast, the CYD report stresses that four trends reveal the universities' deterioration: the lack of international competitiveness of Spanish universities; the incapacity of the Spanish economy to be competitive in international markets via the university system; the lack of resources for science, technology, and knowledge transfer; and the failure of public administrations to attach importance to university policies and the allotment of resources.

Figure 1: Triangle of knowledge

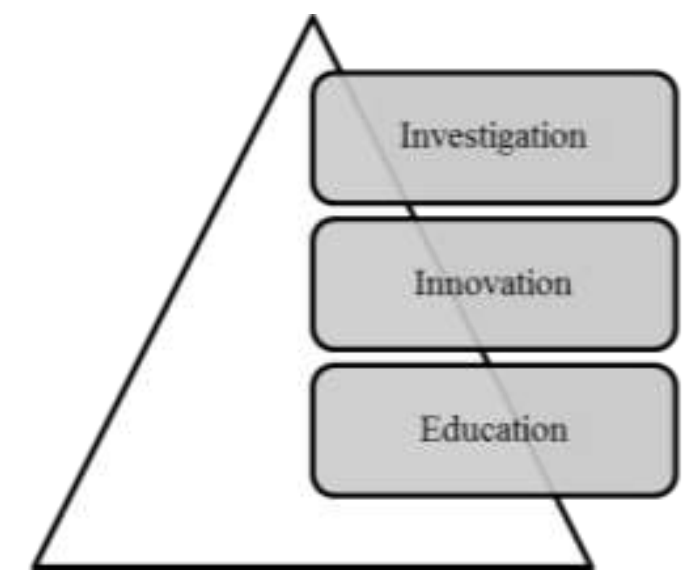

Source: Author.

\section{The compass of governance}

In recent years, public universities in Spain have witnessed many changes. These transformations are closely related to the evolution of the Spanish State since the birth of its parliamentary democracy, the development of the Welfare State, and its membership in the European Union.

Reflection on the role of universities is now common in many member states of the OECD. In times of economic crisis and changes in social structures, university systems are seeing their very essence being questioned. Not only are they expected to contribute to the training of human capital and to the development of research and innovation, but at the same time they must respond to a series of crucial challenges. Among these are the achievement of a high quality level that can measure up to international comparisons, improved governance and accountability, and increased resources and diversification of funding sources (Eurydice, 2009).

When we speak of universities we are referring to a key institution, a social driving force, but many see its progress as far too slow. In the words of Carlos Mas, then Chairman 
of PricewaterhouseCoopers (PWC) Spain, the university sector "seems to progress at too slow a pace as a result of bureaucratic obstacles and practices rooted in the past" (PWC, 2013, p. 4).

In recent years, with the aim of increasing governance capacity and autonomy, Spanish universities have embarked upon setting up a new legal framework that - steered by the parameters of funding, teaching, and organizational autonomy - has moved it towards the new model of public administration: the "new public management" (Smailovich, 2007).

The regulatory scenario that has favoured the establishment of institutional restructuring processes in Spain started with the adoption of the 1978 Constitution, which in Section 27.10 states "the autonomy of universities is recognized, under the terms established by law." Such recognition gave rise to a concerted effort to draft regulations, which materialized with the enactment in 1983 of the Ley de Reforma Universitaria (University Reform Act/LRU). The LRU introduced significant changes in the organization and governance of public universities in Spain, and marked the transition from a university system structured according to classic parameters to one that looks to the Humboldtian model. This evolution involved the democratization of universities and the transformation of the structure of education, all garnished with the implementation of university autonomy understood in terms of a quest for results.

The 2001 Ley Orgánica de Universidades ${ }^{3}$ (Universities Act/LOU) provides for the design of a modern regulatory architecture demanded by the Spanish university system to improve its quality of teaching, research, and management. University autonomy was boosted and the requirement for functional accountability was increased.

Improvements in university management and administration were put forward as instruments needed to tackle social changes that were accompanied by demands, as well as continuous renewal, where universities would occupy a privileged position linked to cultural, scientific, and technical development. To this end, higher education institutions were called upon to increase their effectiveness, efficiency, and responsibility as a matter of urgency, all these being core principles of university autonomy itself.

This development of internal university governance and university autonomy cannot be considered in isolation, but rather exacts an analysis of the proper exercise of such autonomy from the perspective of the corporate social responsibility of universities. Modernization, understood in terms of efficiency and de-centralization, the development of autonomy as seen in the fulfilment of responsibilities and control of results, and the increase in teaching staff qualifications, both legal and professional, are some of the governance issues that the Spanish state is currently considering, under pressure from the strategic policies of international organizations, described by some as "political entrepreneurs" (Jakobi \& Martens, 2007).

\footnotetext{
${ }^{3}$ Subsequently modified by the Law 4/2007 on Universities (also known by the abbreviation LOMLOU).
} 


\section{The sustainability of funding in higher education}

The funding of Spanish public universities is a recurring theme in the debate about university policies. However, it is far from being resolved, and is not seen as an isolated case that escapes the attention of all other European countries. The global financial crisis has prompted different governments to reformulate their funding mechanisms in this field in the struggle to ensure financial sustainability, effectiveness, and efficiency. Thus, competition for funding is becoming a process, a political practice that is "re/de/forming" Higher Education (Daza et al., 2015, p. 149)

In recent decades, the Spanish public university system has witnessed unprecedented growth. Gradual funding from public sources has been a determining factor in the consolidation of this trend, safeguarded by a surge in economic growth that the country benefited from until 2007, the year in which the global economic crisis burst forth (Escardíbul \& Pérez, 2013).

According to the 2013 CYD report, some significant aspects of funding and investments in Spanish higher education can be highlighted:

- In 2009 , expenditure per student $(\$ 13,600)$ was similar to that of the EU$21(\$ 12,790)$, but below that of OECD countries $(\$ 18,570)$.

- Expenditure as a proportion of GDP in Spain (1.31\%) is slightly less than the average of the EU-21 countries (1.43\%) and those of the OECD (1.58\%).

- Expenditure in higher education in comparison with that of the whole of the public sector $(2.5 \%)$ is below the averages of the EU-21(2.7\%) and the OECD (3.1\%).

There are two important characteristics that define Spanish public university spending in the past few years and its recent evolution. Funding comes from two sources: institutions (90\%), and, although to a very limited extent, from students' fees and other items (10\%). Thus, expenditure on higher education institutions in Spain in general is spread out as follows: $79 \%$ from public sources, $17 \%$ from fees, and $4 \%$ from other private enterprises (Michavila, 2012).

As a result of the transfer of education competencies, it is now the Autonomous Communities that support the structural funding of universities. The most significant contribution comes from this source, together with funds from the private sector, mainly in the form of the fees users pay for tuition and registration. In this sense, a model based on unconditional funding gradually became consolidated, one that was not linked to the achievement of objectives or academic management. In general terms, the funding scheme for the Spanish university system can be said to belong to a European model; unlike in other parts of the world, this model is characterized by the dominance of public funding, with low registration fees and an increasing spending rate with respect to the GDP as the levels of state development increase. Garrido (2013) has identified three world models of funding as the most common. These are the American model, whose revenue is obtained essentially through private means (registration and tuition fees, patronage, athletics, and sponsorship); the Scandinavian-German model, which is the antithesis of the previous one, 
with completely free university tuition defrayed by the State; and that of British institutions, with limited state funding supported by income from fees and research.

Thus, if we wish to preserve this traditional structure, in which the Spanish State itself is the main contributor to university funding, the whole tax system would need to be redesigned to be able to cope with public funding, and this is money that the state simply does not have. In light of this, and in this context marked by the governance compass, it is clear that the traditional funding structure is losing momentum and is gradually giving way to the idea of a distribution of funds subject to outputs, performance, and the demands of quality criteria.

In this climate governed by the challenge of excellence, an appeal is made to a market-oriented Higher Education system. Moreover, it is easy to find manifestos that claim that "Europe and all countries should dismantle their Higher Education system with good financial support from the State and imitate the USA" (López Segrera, 2009, p. 525). The discourse that tends to devalue Spanish universities is based on the North-American University system, as a reference owing to its visibility in international rankings. In this model, public universities receive funding from the federal and state administrations, with the result that "the continual search for private and public funding is an incentive to maintain the highest levels of excellence since, if not, the funds available are assigned to other centres, attending to criteria of competitiveness and merit" (Canosa, 2007, p. 2).

However, some studies have shown that, overall, Spanish public universities give the investments with which they have been endowed back to the society that supports them (PWC, 2013, p. 4). In the paper entitled "The Economic Contribution of the Spanish University System," Pastor and Peraita (2012) provide evidence that public spending on the SUS is profitable and should indeed be considered an investment in human capital by Spanish society. In general terms, the results indicate that public spending in university education has highly positive effects on economic productivity. We refer here to contrasted evidence pointing to the dangers of making biased readings based on international positioning alone.

At this point, it may be suggested there are two trends in this financial dimension. First, we are witnessing a gradual increase in the costs of teaching and, second, we are seeing a boom in movements pressing for the adoption of principles of austerity in the management of public resources and the implementation of spending cuts, including a very poignant reduction in funds allocated to the running of Spanish public universities.

\section{Teaching costs and principles of austerity}

In April 2012, the Popular Party Government enacted a Royal Decree ${ }^{4}$ announcing cuts in public spending on education. Among the main measures was an increase in university registration fees, which until that moment had increased in line with the consumer price index. From that moment on, the Autonomous Communities were to fix their own university fees, within the limits established by the General Conference on University

\footnotetext{
${ }^{4}$ Royal Decree-Law 14/2012 of 20 April on urgent measures for streamlining public spending in education
} 
Policy, and these were to be linked to the $\operatorname{cost}^{5}$ of providing university services. Consequently, the conditions in each region, and in particular its targets for repaying its deficit to the administration, would lead to a greater or lesser increases in fees.

In this sense, regarding public university ${ }^{6}$ tuition fees, emphasis should be placed on the huge disparity that exists among the different Autonomous Communities. This is due, on one hand, to historical reasons triggered by the takeover of powers and the differentiation of university policies and, on the other, to the amount experimental work involved in the various courses offered. Thus, for example, medical studies are the most costly, whereas the Arts and Literature are "cheaper."

Table 1: Prices of graduate degree courses, Spanish public universities, 2013/2014

\begin{tabular}{|l|}
$\begin{array}{l}\text { Increase from } 2012 / 2013 \\
2.9 \%\end{array}$ \\
$\begin{array}{l}\text { Average cost, first registration, all specialties, all communities } \\
€ 18.42 / \text { credit }\end{array}$ \\
$\begin{array}{l}\text { Average costs, course of } 60 \text { credits, without repetition of registration } \\
\text { 1.105 }\end{array}$ \\
\hline $\begin{array}{l}\text { Galicia (lowest) } \\
€ 11.89 / \text { credit }\end{array}$
\end{tabular}

Source: Author's elaboration from the MECD (2014): Basic data on the Spanish University System.

In the case of postgraduate studies (Master's degrees), a distinction can be made between those that prepare students to enter the job market ("enabling") and those that do not ("non-enabling"). The average cost of the former for the 2013/2014 academic year was $€ 26.89$ per credit, and for the previous year $€ 40.11$. A trend towards a reduction in prices can be observed with regard to the previous years. In this case, there is not as much heterogeneity with respect to experimental work as in undergraduate courses. In fact, many of the Autonomous Communities have decided to maintain the same fees without making a distinction between the two Master's modes (enabling vs. non-enabling). Table 1 summarizes trends in the cost of graduate degree courses.

\footnotetext{
${ }^{5}$ For example, with regard to prices for undergraduate courses at public universities, this price will cover between $15 \%$ and $25 \%$ of costs of the initial registration fee, between $30 \%$ and $40 \%$ of a second registration fee, between $65 \%$ and $75 \%$ of costs of a third registration, and between $90 \%$ and $100 \%$ of costs of fourth and subsequent registration fees.

${ }^{6}$ It should be noted that currently it is difficult to access information that will allow comparisons between the fees applied by public universities and those set by private higher education institutions for the same programs of study. It would appear that there is considerable disparity, but such an analysis lies outside the scope of this work.
} 
Figure 2: Average fees ( $€ / c r e d i t)$ in Spanish public universities for students registered in first, second, third, fourth, and successive registrations for undergraduate courses, by Autonomous Communities, 2013/2014

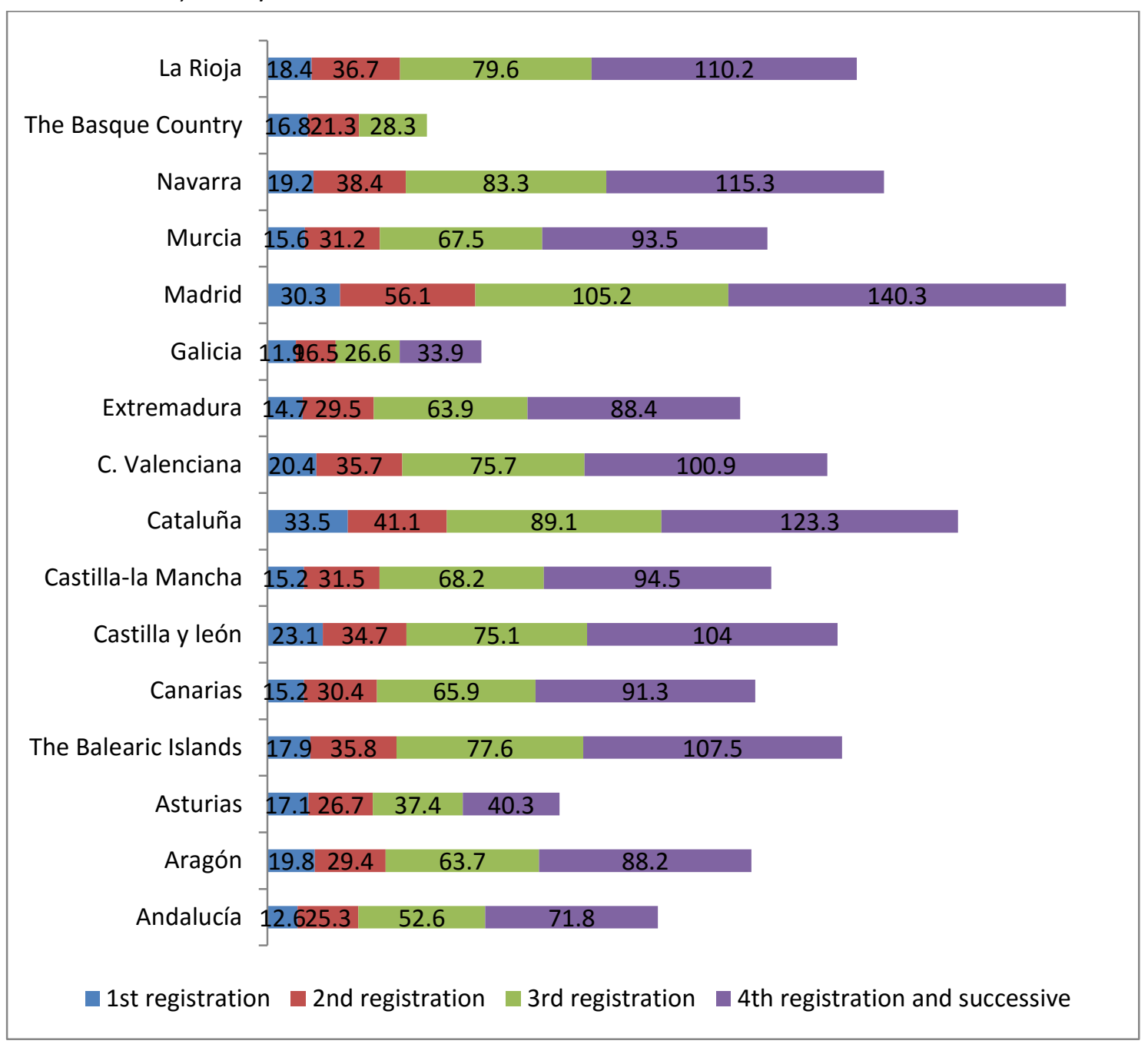

Source: Author's elaboration from the MECD (2014): Basic data on the Spanish University System.

Regarding doctoral courses, again we find significant differences across the various Autonomous Communities. The average price for academic supervision (per Royal Decree $99 / 2011$ ) is set at $€ 259.61$ and the fee for the defense of doctoral dissertations is $€ 152.93$.

In keeping with the criteria mentioned earlier, set by this new governance mode (seeking results from educational institutions), special mention should be made of students who repeat subjects. A penalization policy has been set in motion through which considerable price hikes have been introduced for the second, third, and fourth registrations in a given course (see Figure 2). Again there exists great disparity between the different Autonomous Communities, giving rise to a very uneven picture across Spain.

This situation is also prevalent in the universities themselves, since those that fail to meet the economic targets will be penalized. In fact, universities have been included in the Budgetary Stability Act and will therefore be subject to such spending control mechanisms. 
Thus, they are obliged to submit accounts of their activities to the Accounts Supervisory Board of the Autonomous Community to which they belong.

Following the line marked by performance assessment culture, the value of effort, and the achievement of excellence through performance, in 2012 Minister Wert also announced new political measures that will toughen the requirements to obtain a university scholarship. To obtain a basic scholarship during the academic year 2013/2014, a score of 5.5 was set for the university entrance exam (excluding the specific subject element). This score rose to 6.5 in the following year. ${ }^{7}$ Likewise, students who obtained these grants will be obliged to pay them back if they do not earn at least half of the credits for the subjects in which they are registered. To renew these scholarships, the criteria have been set based on a specific minimum number of credits, and not just on financial need (means testing).

Consistent with these guidelines, in Order ECD/1997/2013 of 24 October, for the academic year 2013/2014 it was established that the students selected for the award of a complimentary Erasmus scholarship - €150/month - must also have been awarded a general scholarship in the previous year; that is, they must have been exempted from paying tuition fees. Many students learned of this initiative, implying the loss of the grant they were expecting to receive, when they were already studying abroad.

Two years after Royal Decree 14/2012 of 20 April came into effect, the rectors of Spanish state universities signed a joint press release (CRUE, 2014) in which they insisted that the exceptional measures affecting studies, teaching activity, and research introduced by that decree be withdrawn. They claimed that the measures taken at that time were presented as exceptional, motivated by the economic conditions of the time, and that in the light of better economic prospects it was necessary to repeal the measures that were above and beyond rational monetary savings and efficient and austere management.

The press release places special emphasis on the plight of young adults and the impact of these regulations on them. At a time when employment prospects are scant, increases in academic fees affect the whole of their educational outlook. Accordingly, reasonable and affordable public prices were called for across all degree levels.

\section{Internationalization as a way of academic excellence}

One of the most important challenges for the future of universities, and especially for knowledge management, is internationalization. It may be stated that "its importance can be seen from the position it occupies in domestic and international agendas in all countries of the world" (Alcón, 2011, p. 32). It is essential to attract international talent and draw in the very best academics and researchers, which is completely unfeasible without proper regulation, funding, and governance.

In 2008, the Spanish government tabled a commitment to boost the 2015 Strategic Plan for Universities, followed by the $2011 / 2012$ plan as an initiative aimed at modernizing

\footnotetext{
${ }^{7}$ Faced with social, political, and academic pressure, the Minister decided not to increase the minimum grade for students to be eligible for exempted-fee scholarships. However, this change will not affect the most substantial scholarships such as those designed to cover living expenses, for which the 6.5 grade stipulated will be maintained.
} 
the Spanish universities in the period between 2010 and 2020. In order to accomplish its aims, the government opted for the promotion of teaching and scientific excellence, internationalization of the university system, and its involvement in economic change based on knowledge and improved innovation -maintaining and encouraging "the social dimension" and the nature of higher education as a public social asset.

This initiative seeks to improve the quality and impact of the SUS and place the best Spanish universities among the top 100 in Europe, as well as installing the most competitive universities overall among the internationally most prestigious ones. Accordingly, "the urgency in carrying out a strategy of the international immersion of our university system stems from the conviction that the globalization of Higher Education and of knowledge will not attend to the countries that most lag behind" (MECD, 2011, p. 4).

Out of the framework for action arose the Campus d'Excellència Internacional (International Campus of Excellence/CEI) program, aimed at supporting and funding strategies and measures to improve the quality level and international outlook of Spanish universities. With this in mind, the universities have drawn up their own Strategic Plans of Action as instruments for defining the path to be taken by their institutions if they are to be brought up to acceptable quality.

It seems clear that with the different attempts at reform, Spanish universities have modernized themselves to align with those of the most advanced countries. However, the perception of our universities is that they are well below where they should be. Crespo (2011) refers to six negative practices that affect universities and that will prevent them competing internationally. Here we refer to overcrowding, "inbreeding," the poor quality of teaching, mediocrity in the field of research, low international influence, and scant economic resources.

The introduction of this efficiency-driven philosophy into the public sphere addressed in this article has brought with it the need to measure the performance of the public administration. The culture of organizational operation based on results has triggered the development of indicators and an extensive range of rankings to calculate and assess the main targets to be met by universities. This mechanism of comparison is considered an exercise in corporate social responsibility that is appropriate and proper for public universities, who must demonstrate their accountability and transparency with regard to the use of the public resources they receive (Romero \& Pastor, 2012).

However, it is crucial to qualify what is meant by excellence, or what requisites must be met, for universities to appear in the rankings that award them such distinction. It was not in vain that Erkkilä and Piironen (2014) emphasized that this type of world classification has been a political problem at the European level, since the poor positions of European universities show signs of a system that is at the very least deficient and is especially worrisome for governing agents due to the lack of visibility and international presence.

According to the latest expert report available, Spain must recognize that the quality of the SUS is deficient and that the lack of universities of excellence is indisputable. 
In this regard, the absence of a single Spanish Nobel Laureate since $1906,{ }^{8}$ low numbers of patent filing, and limited research publications in influential international journals have been highlighted. It has even been suggested that a university education does not facilitate Spanish university students' access to a job commensurate with their qualifications.

Nevertheless, the strategy that the rankings used for assessing all the universities at once errs widely by failing to take into account the peculiarities of each of them, thereby introducing biases against universities whose specialization in areas such as the social sciences and humanities is less valued (Romero \& Pastor, 2012). Therefore, the subjectivity underlying the strategy must be borne in mind since sometimes not all the factors that can contribute to academic excellence are taken into consideration. This impartiality is not at odds with international relevance, which means that we have no other choice than to take the rankings into account.

It is claimed that Spain not only has no internationally prestigious universities but also that it hosts a very low percentage of students from other countries. The Education at a Glance 2013: OECD Indicators report highlights the fact that in 2010, the share of international students compared to the total number of students in tertiary education across OECD countries reached 8\%, while in Spain it was only 3\%. The comparison worsened for undergraduate university studies: a ratio of $7.8 \%$ in the OECD and only $2 \%$ in Spain. In fact, of the OECD countries that provide data on international students (26), Spain was only ranked higher than Slovenia, Norway, Poland, and Chile. Finally, in 2010 the highest proportion of international students was found for postgraduate university courses: a share of $21.1 \%$ across OECD countries and $12.2 \%$ in Spain, which at that time ranked higher than eight countries in hosting international students (Finland, Portugal, Slovenia, Slovakia, Estonia, Hungary, Norway, and Poland). The majority of international students enrolled at Spanish universities in 2010 were registered in the fields of the social sciences, business studies, and law (32.6\%); the health sciences (26\%); the humanities, the arts, and education (16.4\%); engineering and architecture (9.5\%); and the natural sciences (7.2\%). In comparison with other OECD countries, Spain stands out particularly in the health sciences, since it is the country with the third highest percentage of international students taking courses in this field.

Recent data from the Spanish university system (MECD, 2014) confirm that the number of foreign students is increasing, rising (in 2012/2013) to 74,297 students, of which 53,832 were degree students, first and second cycles, and 20,465 were Master's students. A trend towards stable growth can be seen in the annual rate of variation for foreign degree students. However, when speaking of Master's students, the trend is decreasing, and in the 2013/2014 year their numbers decreased.

In this scenario, internationalization is usually linked to academic mobility. Along the past few years, international student exchange has been articulated through many programs, the best known and accepted being the European Community Action Scheme for the Mobility of University Students, known as Erasmus.

${ }^{8}$ This Prize was awarded to Santiago Ramón y Cajal. The Prize awarded to Severo Ochoa in 1959 belongs to the USA. 
The current situation reflects an increase in the number of students participating in this initiative, supporting the evidence that "Erasmus has more than fulfilled its duty of fostering mobility, with previously unimagined figures" (Valle \& Garrido, 2014, p. 42). The powerful evolution undergone by this initiative since its beginnings is noteworthy and in the 2012/2013 academic year, student numbers reached 268,143, with the total number for all years coming to 3,000,000 (one million in 2001/2002 and two million in $2007 / 2008$ ). Thus, "international mobility is now an established fact and Spain finds itself among those countries that receive the most foreign students through Erasmus grants" (Giménez-Salinas, 2010, p. 51). In this way, Spain is perceived as an attractive country for receiving students, although it would be worthwhile asking ourselves whether this is sufficient or whether it would be necessary to take measures to obtain further advantages from this reality. Alcón (2011) reports that in the past living expenses and the recognition of studies were the main obstacles faced by students. This situation has now changed and currently the language barrier and funding are the main worries.

These pitfalls have become even more severe with the most recent political events in Spain, through which the criteria for the award of an Erasmus grant have toughened considerably. Thus, recent measures taken by the government, under the Ministry of Education through the Erasmus + program, announced more restricted student selection when establishing the endowments. Those with the best academic records and an accredited high level of the language of the host country will receive more money than students who do not meet these requirements. Also, the duration of a stay in another country has been halved.

According to the Ministry of Education itself, of the 10,000 awards foreseen for the next academic year, 8,857 have been granted, which means that some 1,100 places (one out of every 10 applications) have been lost. The main reason lies in the lack of language accreditation (level B2). Warnings about this measure have emerged from the campuses, highlighting the notion that the reasons why they have been implemented are not so much based on the search for excellence, as stated by the government, but on implementing funding cuts, the saving of public money.

In this scenario, internationalization is thus conceived as a fundamental instrument in the knowledge management provided by universities. It has become a strategic activity for recruiting undergraduate, postgraduate, and doctoral students. Initiatives such as the University Campus of Excellence and the mechanism of international comparison via rankings have taken root as instruments for international outreach.

\section{Conclusions}

Gazelles and Lions. The gazelle knows that if it doesn't want to be eaten by the lion, it doesn't have to run faster than its attacker, only faster than the other gazelles. With his metaphor, Ferrer (2010) tries to create a parallelism between gazelles and universities, with the understanding that if Spanish universities wish to stand out in the international arena, they must not be content with simply improving; they must improve much faster than other universities around the world. And to achieve this, they must make a sea-change in their strategies and ways of governance. 
No one can question the huge progress that the SUS has made recently or the central role that it plays in the cultural, economic, and social development of the country. This article has outlined the changes that the higher education and university research system has undergone and the challenges it faces in the future. Consequently, these challenges, among others, affect university specialization, the diversification of funding sources, the fostering of internal mobility, and the necessary internationalization of institutions along the lines already set out by International Campuses of Excellence.

The identification of public universities with other social or economic organizations has led it to redirect its mission and aims, losing influence and with its social functions blurred, and to seek efficiency in its performance. Contributing to this has been the dominance of new public management thinking, which has among its basic postulates the non-differentiation between the public and private sectors, based on more neo-liberal economic trends.

As stated in the introduction, the arguments used in debates about university reform were sparked by two opposing stances. On one hand are those who defend and criticize the existence of groups resistant to change and progress, who cling to unproductive forms and sentiments, and who would justify all political measures imposed by the Spanish government aimed at achieving profitable objectives. On the other hand, there are those who warn of the dangers of certain power groups who seek to turn universities into institutions governed purely by the free-market system, setting aside their social role.

The line of the present work addresses the controversy brought to us in the form of the report of the Expert Committee (mentioned above) and the desirability of "yet another" university reform in Spain. This proposal has been received with great hostility by a large sector of the academic community, especially the Conference of Rectors, the CRUE, lecturers' unions, and students' associations in general. Nevertheless, it seems that the initiative has not made much of an impression. In general, Spanish society has stood on the sidelines of the debate as if affairs of this kind were best handled internally. This reflects the situation that has accompanied the university sector throughout its history: its "inbred" nature and its impenetrability.

All proposals for reform imply the admission that there are aspects that can be improved. It would seem that this is a point of departure and union; perhaps discrepancies will emerge when it comes to establishing the channels, mechanisms, and initiatives to be adopted for real progress to be made.

Thus, the challenges posed all revolve around the issue of excellence. What is sought is international visibility through a quality university sector that meets the imperatives set by global societies. And on this pathway, we are beset with pitfalls. It is simply not sufficient that European students should choose Spain as a place to spend a few months studying. Thus, the data on foreign students studying in Spain are scant, pointing to a clear deficiency. In turn, we must recall that when we speak of internationalization this also means adding non-Spanish citizens to our university departments and in processes of selection, an aspect that in Spanish universities is far from reality.

However, Spain runs the risk of turning to her neighbours and their university models and clumsily copying other academic formulas. These are doomed to failure if they 
are not adapted to the peculiarities of the country. In Ortega y Gasset's words, Spain should "seek the information from abroad, but not the model."

It is striking that Spanish university education should be of such deficient quality when it is a country with eight centuries of academic tradition. It certainly deserves more and better support; if not, it will succumb in an increasingly competitive world.

\section{References}

Alcón, E. (2011). La internalización de los estudiantes universitarios. La cuestión Universitaria, 7, 32-39.

Aunión, J. A. (2013, March 18). El eterno retorno de la reforma universitaria. El País.

Arenilla Sáenz, M. (Ed.). (2012). La reforma de la Universidad española. Un análisis desde su gobernanza. La Coruña, Spain: Netbiblo.

Daza, S., Subreenduth, S., Rhee, J., \& Proctor, M. (2015). Funding re/de/form in higher education: Diverse points of engagement. In K. M. Sturges (Ed.), Neoliberalizing educational reform: America's quest for profitable market-colonies and the undoing of public good (pp. 149-184). Rotterdam, Netherlands: Sense Publishers.

de Azcárraga, J. A. (2013). Sobre la conveniencia de una reforma universitaria. http://www.uv.es/ azcarrag/pdf/15-Ag13\%20\%20Azcarraga\%20Defensa\%20Informe.pdf

Besalú, X., Marqués, S., \& Soler, P. (2013). Excelencias universitarias. Revista Sinpermiso. http://www.sinpermiso.info/textos/index.php?id=5801

Canosa, J. (2007). Universidades norteamericanas, universidades europeas. Libertad Digital IDEAS.

http://www.libertaddigital.com/opinion/ideas/universidades-norteamericanasuniversidades-europeas-1276233507.html

Comité de Expertos. (2012). Propuesta para la reforma y mejora de la calidad y eficiencia del sistema universitario español.

http://www.mecd.gob.es/prensa-mecd/dms/mecd/servicios-al-ciudadanomecd/participacion-publica/sistemauniversitario/propuestas-reforma.pdf

Crespo Maclennan, J. (2011). La internacionalización de la universidad española y su contribución a la proyección exterior del país. Real Instituto El Cano (ARI). http://www.realinstitutoelcano.org/wps/portal/rielcano/contenido?WCM GLOBA L CONTEXT=/elcano/elcano es/zonas es/lengua+y+cultura/ari39-2011

CRUE. (2014, April 30). Comunicado conjunto 'para solicitar el fin de las medidas excepcionales.'

http://www.crue.org/Documents/2014.04/2014.04.30\%20Comunicado\%20CRUE. pdf

CRUE. (2012, April 17). Los rectores de las universidades españolas manifiestan su preocupación por las recientes declaraciones del Ministro de Educación, Cultura y Deporte, sobre el Sistema Universitario Español. 
http://www.crue.org/PrensaYComunicacion/SalaPrensa/Paginas/Comunicadosde-la-CRUE.aspx?Mobile $=0$

Eurydice. (2009). El gobierno de la educación superior en Europa: Políticas, estructuras, financiación y personal académico. Brussels, Belgium: European Commission.

Erkkilä, T., \& Piironen, O. (2014). Shifting fundaments of European higher education governance: Competition, ranking, autonomy and accountability. Comparative Education, 50(2), 177-191.

Escardíbul, J., \& Pérez, C. (2013, April-September). La financiación de las universidades públicas españolas: Estado actual y propuestas de mejora. Revista de Educación y Derecho (8).

Ferrer, L. (2010). Gacelas y leones: Reflexiones sobre gobernanza y estrategia de las universidades españolas. In D. Peña (Ed.), Propuestas para la reforma de la Universidad española (pp. 27-38). Madrid, Spain: Fundación Alternativas.

Fundación Conocimiento y Desarrollo. (2013). Informe anual sobre la contribución de las universidades españolas al desarrollo. Barcelona, Spain: CyD.

Garrido Ardilla, J. A. (2013, April 17). La financiación de la universidad española. El Norte de Castilla.

Girotto, M., Mundet, J., \& Llinás-Audet, X. (2013, May-August). Estrategia en la universidad: ¿Cuestión de calidad, gerencialismo y relaciones político-financieras? Revista de Educación, 361, 95-116.

Grau Vidal, F. X. (2012). La universidad pública española. Retos y prioridades en el marco de la crisis del primer decenio del siglo XXI. Tarragona, Spain: URV.

Jacobi, A., \& Martens, K. (2007). La influencia de la OCDE en la política educativa nacional. In X. Bonal, A. Tarabini-Castellani, \& A. Verger (Eds.), Globalización y educación: Textos fundamentales (pp. 233-253). Buenos Aires, Argentina: Miño y Dávila.

López Segrera, F. (2009). Reflexiones en torno a la financiación actual y futura de las universidades a nivel mundial. Avaliação, Campinas, 14(3), 523-560.

Llinás-Audet, X., Girotto, M., \& Solé, F. (2011, May-August). La dirección estratégica universitaria y la eficacia de las herramientas de gestión: El caso de las universidades españolas. Revista de Educación, 355, 33-54.

Martínez, R. (2012): Reflexiones en torno al sistema de gobierno de las universidades ante el reto de la modernización de la gobernanza universitaria. Revista catalana de dret públic (44). http://www10.gencat.net/eapc revistadret/revistes/revista.2011-04$15.8170269681 /$ Reflexiones en torno al sistema de gobierno de las universidade s ante el reto de la modernizacion de la gobernanza universitaria/es

MECD. (2014). Datos básicos del sistema universitario español. Curso 2013/2014. Madrid, Spain: Ministerio de Educación Cultura y Deporte.

http://www.mecd.gob.es/dms/mecd/educacion-mecd/areas-

educacion/universidades/estadisticas-informes/datoscifras/DATOS CIFRAS 13 14.pdf

MECD. (2011). La contribución del talento universitario en el futuro de la España 2020: Internalización, experiencia y empleabilidad. Madrid, Spain: Ministerio de Educación Cultura y Deporte. 
http://www.mecd.gob.es/dctm/ministerio/horizontales/prensa/documentos/201 1/07/20110713-futuroespanol?documentId=0901e72b80d8f42c

Michavilla, F. (Ed.). (2012). La universidad española en cifras. CRUE.

OCDE. (2013). Panorama de la educación 2013. Indicadores de la OCDE. Informe español. http://www.mecd.gob.es/dctm/inee/internacional/panoramadelaeducacion2013in forme-espanol.pdf?documentId=0901e72b816996b6

Pastor, J. M., \& Peraita, C. (2012). La contribución socioeconómica del sistema universitario español. Madrid, Spain: Ministerio de Educación, Cultura y Deporte.

PWC. (2013). Temas candentes de la universidad española 2013 ¿Tenemos la universidad pública que necesitamos?

http://kc3.pwc.es/local/es/kc3/publicaciones.nsf/V1/7E7ABBBC81074258C1257 B33005EA050/\$FILE/Temas-Candentes-Universidad.pdf

Romero, J., \& Pastor, J. M. (2012). Las universidades españolas bajo la influencia de los rankings. Regional and Sectoral Economics Studies, 12(3), 105-126. http://www.usc.es/economet/journals2/eers/eers1238.pdf

Smailovich, D. (2007, August). Escenarios de gobierno en las universidades Europeas. Colección Documentos Fundación CYD. http://www.fundacioncyd.org/wps/portal/WebPublica/General?WCM GLOBAL CO NTEXT=/WebCorporativa es/webfcyd es/publicacionescyd/documentosfcyd/

Valle, J., \& Garrido, R. (2014). Los flujos de movilidad ERASMUS al término del programa Lifelong Learning y comienzo del Erasmus + RIESED. Revista Internacional de Estudios sobre Sistemas Educativos, 2(3), 37-57. 